\title{
SOX15 and other SOX family members are important mediators of tumorigenesis in multiple cancer types.
}

\author{
Kelsie L. Thu ${ }^{1}$, Daiana D. Becker-Santos ${ }^{1}$, Nikolina Radulovich ${ }^{2}$, Larissa A. Pikor ${ }^{1}$, \\ Wan L. Lam ${ }^{1}$, Ming-Sound Tsao ${ }^{2}$ \\ ${ }^{1}$ BC Cancer Research Centre, Vancouver, B.C., Canada \\ ${ }^{2}$ Ontario Cancer Institute, Princess Margaret Hospital, University Health Network at the University of Toronto \\ Correspondence to: Wan L. Lam, email: wanlam@bccrc.ca \\ Keywords: SOX, SOX15, oncogene, tumor suppressor, development, cancer \\ Received: May 20, 2014 \\ Accepted: May 31, 2014 \\ Published: June 2, 2014
}

This is an open-access article distributed under the terms of the Creative Commons Attribution License, which permits unrestricted use, distribution, and reproduction in any medium, provided the original author and source are credited.

\section{ABSTRACT:}

SOX genes are transcription factors with important roles in embryonic development and carcinogenesis. The SOX family of $\mathbf{2 0}$ genes is responsible for regulating lineage and tissue specific gene expression patterns, controlling numerous developmental processes including cell differentiation, sex determination, and organogenesis. As is the case with many genes involved in regulating development, SOX genes are frequently deregulated in cancer. In this perspective we provide a brief overview of how SOX proteins can promote or suppress cancer growth. We also present a pan-cancer analysis of aberrant SOX gene expression and highlight potential molecular mechanisms responsible for their disruption in cancer. Our analyses indicate the prominence of SOX deregulation in different cancer types and reveal potential roles for SOX genes not previously described in cancer. Finally, we summarize our recent identification of SOX15 as a candidate tumor suppressor in pancreatic cancer and propose several research avenues to pursue to further delineate the emerging role of SOX15 in development and carcinogenesis.

\section{INTRODUCTION}

SOX genes (SRY-related high mobility group (HMG) box) encode a family of transcription factors containing the DNA binding domain of SRY, the first SOX gene identified [1-3]. The twenty different SOX proteins identified in mammals to date can be subdivided into 8 groups (A-H) based on similarities in HMG box domains, gene structure, and the presence of specific functional domains including coiled-coil, transactivation and transrepression domains $[2,4]$. Depending on the domains present and their specific binding partners, SOX proteins can either activate or repress the expression of target genes in a tissue-specific manner $[1,2,5,6]$. Through their lineage-specific modulation of gene expression, SOX proteins are involved in embryonic development, regulating processes such as cell differentiation, maintenance of stemness, sex determination, and development of the central nervous, haematopoietic and other organ systems $[1,2,5]$. As $S O X$ members are critical regulators of cellular programming, it is not surprising that disruption of these genes has been implicated in several human diseases including cancer $[1,2,7]$.

Roles of SOX proteins in cancer and cancerassociated pathways

Embryonic development is a tightly regulated process involving differentiation of cells into specialized cell types and rapid cell growth. It is well established that numerous genes and pathways with essential roles in development are frequently disrupted to promote carcinogenesis, which itself is characterized by aberrant cell proliferation and/or differentiation. The disruption of SOX proteins in various malignancies is a case in point. 


\section{Oncogenic and suppressive roles of SOX proteins in tumorigenesis}

SOX family members may act as oncogenes, tumor suppressor genes, or both depending on the cellular context, and can be activated or inactivated through a variety of genetic and epigenetic mechanisms including DNA copy number alterations, DNA methylation changes and aberrant miRNA expression [1, 2, 8, 9]. For example, in squamous esophageal, non-small cell and small cell lung cancers, SOX2 acts as an oncogene and is activated through DNA amplification $[10,11]$. SOX2 promotes cell proliferation, anchorage independent growth and is capable of transforming transbronchial epithelial cells $[10,11]$. SOX9 is another example of an oncogenic SOX protein that is overexpressed in multiple cancer types including colorectal, glioma, and pancreatic cancers [12-14]. In contrast, $S O X 7$ is downregulated via DNA deletions and methylation silencing, acting as a tumor suppressor gene in prostate, colon, lung, and breast cancers through its involvement in cell death, movement, invasion and proliferation $[15,16]$. SOX4 appears to have a context-dependent role in cancer as it is upregulated and promotes growth of leukemia, colorectal, lung and breast cancers, but is underexpressed and suppresses growth of bladder and liver cancers [9]. SOX4 is disrupted through DNA copy gains, epigenetic changes involving DNA methylation and miRNAs, and sequence mutations $[8,9]$. It mediates its oncogenic function via several mechanisms including suppression of apoptosis, promotion of metastasis, and maintenance of cancer-initiating cells. Similar to $S O X 4, S O X 2$ and $S O X 9$ have also been shown to have tumor suppressive effects in specific cancer types (gastric cancer and melanoma, respectively), further emphasizing the context specific nature of $S O X$ involvement in carcinogenesis $[17,18]$. The differing actions of SOX proteins in cancer cells of various origins and genetic backgrounds likely underlie the disparate behaviors of SOX proteins in promoting or inhibiting tumor growth [9].

\section{SOX gene disruption in various cancer types}

Not surprisingly given the known involvement of SOX members in cancer biology, a pan-cancer analysis of SOX expression using publically available RNA-
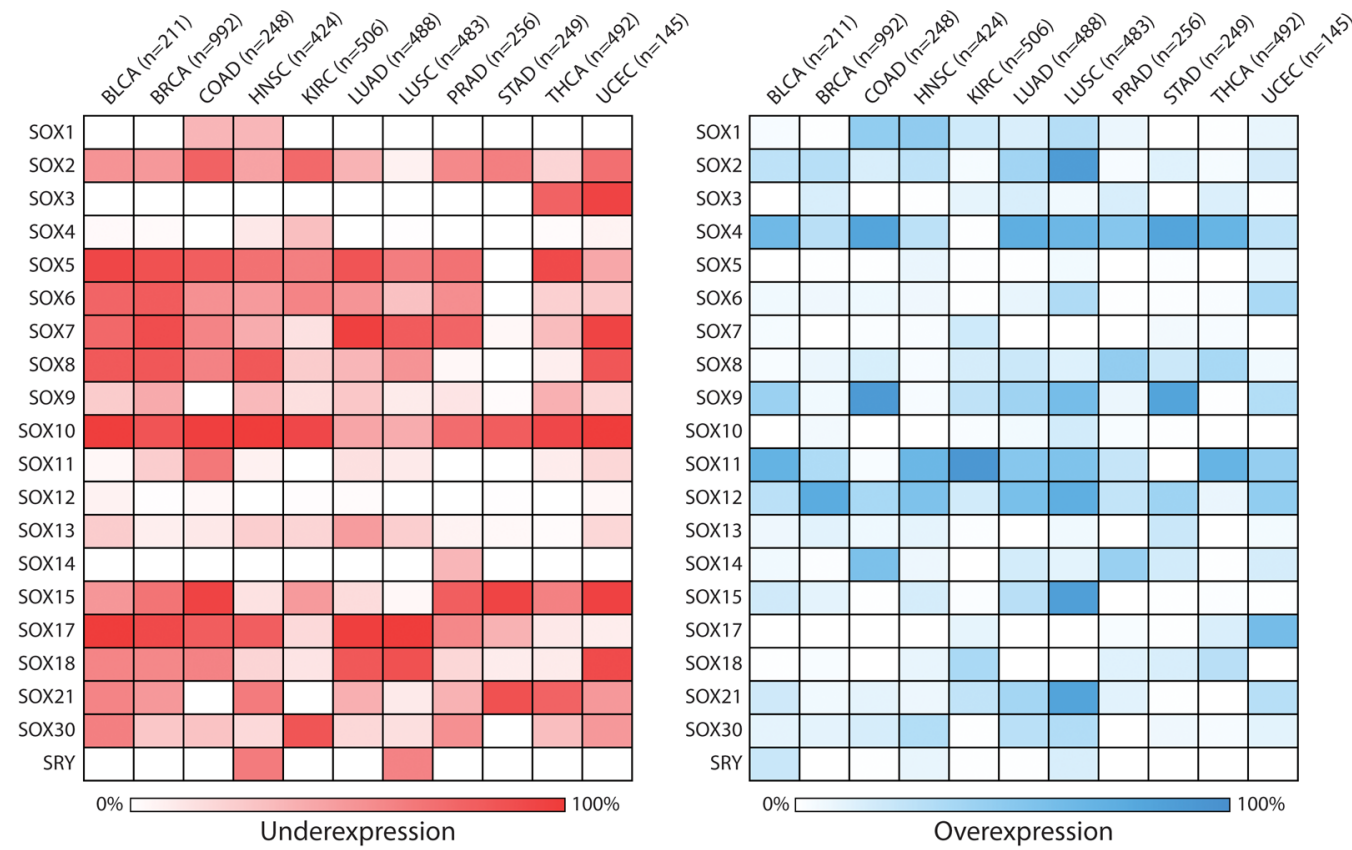

Figure 1: Pan-cancer analysis of SOX gene expression levels. Processed Cancer Genome Atlas (TCGA) SOX family gene expression data for tumor and non-malignant tissues from 11 different cancer types was downloaded from the UCSC Cancer Genomics Browser (https://genome-cancer.ucsc.edu/) [92]. The number of tumor samples for each cancer type is indicated in brackets. Gene expression was classified as over- or underexpressed in individual tumors if tumor expression was at least 2-fold more or less than the average expression of available tissue matched non-malignant samples, and the frequency of expression changes across tumors of each type was calculated. Darker coloration indicates a higher frequency of alteration as indicated in the legends below each heatmap, with underexpression depicted on the left in red and overexpression on the right in blue. Genes were considered recurrently, aberrantly expressed within a particular cancer type if they exhibited a $20 \%$ or greater frequency in disruption. Cancer types are annotated as follows: BLCA bladder urothelial carcinoma; BRCA - breast invasive carcinoma; COAD - colon adenocarcinoma; HNSC - head and neck squamous cell carcinoma; KIRC - kidney clear cell carcinoma; LUAD - lung adenocarcinoma; LUSC - lung squamous cell carcinoma; PRAD - prostate adenocarcinoma; STAD - stomach adenocarcinoma; THCA - thyroid carcinoma; UCEC - uterine corpus endometrioid carcinoma. 
sequencing data for 11 cancer types from The Cancer Genome Atlas (TCGA, http://cancergenome.nih.gov) revealed that $S O X$ genes are frequently deregulated in several human malignancies (Figure 1, Supplemental Table 1). These results corroborate numerous reports of aberrant $S O X$ gene disruption in various cancer types such as overexpression of $S O X 2$ in lung squamous cell carcinoma [8], low expression of $S O X 10$ in epithelialderived carcinomas [19], as well as overexpression of $S O X 4$ and SOX11 and underexpression of SOX7 and $S O X 17$ in a variety of cancer types $[1,2,9,10,16-18$, 20-54]. Our analysis also identified deregulated $S O X$ genes such as $S O X 12$ and $S O X 30$, which have not been well characterized in the context of cancer, suggesting these genes may be worthwhile candidates for further investigation. Many of these RNA expression changes have also been demonstrated at the protein level as evident in the Human Protein Atlas (e.g. SOX4, SOX7, SOX10, SOX17) [55].

The most recurrently deregulated SOX genes, arbitrarily defined here as having a minimum 20\% frequency of deregulation in at least 9 of the 11 different cancer types, included underexpression of $S O X 2$ (10/11), SOX5 (10/11), SOX6 (10/11), SOX7 (9/11), and SOX10 $(11 / 11)$ and overexpression of $S O X 4$ (10/11), SOX11 $(9 / 11)$, and $S O X 12$ (9/11) (Figure 1, Supplemental Table 1). Interestingly, although it has been suggested that $S O X$ genes are predominantly oncogenic in cancer and we found that many were overexpressed [8], we also observed recurrent underexpression of $S O X$ genes in tumors relative to matched non-malignant tissues. In the 11 TCGA cancer types we considered, 13/20 SOX genes showed transcriptional downregulation $(\geq 20 \%)$ whereas only $5 / 20$ showed recurrent upregulation $(\geq 20 \%)$ in at least 5 cancer types. Of the 13 recurrently underexpressed $S O X$ genes, $S O X 3$, SOX5, SOX7 and SOX10 were exclusively underexpressed (i.e. they showed overexpression frequencies $<20 \%$ in all cancer types). We speculate that the prominence of $S O X$ underexpression may be due to the functional redundancy of individual $S O X$ genes $[5,7]$, as loss of function could require inactivation of multiple $S O X$ family members. For example, $S O X 5$ and $S O X 6$, members of the $S O X D$ family, were frequently underexpressed concurrently in several cancer types (Figure 1). Most $S O X$ genes were either over- or underexpressed within individual cancer types, though some exceptions were evident. $S O X 2$ and $S O X 9$ both exhibited frequent over- and underexpression within the same cancer type, potentially indicating their dual roles in cancer and that they could be differentially selected for in cells with different genetic backgrounds. The $S O X$ genes least often disrupted at the expression level were $S O X 14, S O X 3$, and $S R Y$.

As mentioned above, several genetic and epigenetic mechanisms have been associated with aberrant SOX expression in cancer. A similar pan-cancer investigation of TCGA genomics data for the same tumor types revealed that $S O X$ genes are recurrently disrupted through copy number and methylation changes, and infrequently by sequence mutations (Supplemental Table 1). DNA amplifications were more frequent than deletions, while DNA hypermethylation was more frequent than hypomethylation at SOX gene loci. It is possible that these DNA-level changes underlie the prominent SOX gene deregulation we observed, although we acknowledge that additional mechanisms likely contribute to $S O X$ expression as well. The prevalence of DNA and RNA alterations affecting $S O X$ genes in various tumor types is strong evidence of their importance to cancer biology.

\section{Malignant phenotypes and cellular pathways modulated by SOX members in cancer}

As described above, SOX proteins can contribute to the malignant phenotype through their abilities to regulate numerous cancer hallmarks including cell proliferation, apoptosis, survival, invasion, migration, differentiation, stemness, senescence, and angiogenesis $[1,2,8,9,56]$. In the context of cancer biology, Wnt/ $\beta$-catenin signaling is the most well documented cellular pathway affected by SOX proteins. This pathway plays important roles in the development of multiple organs and is aberrantly activated in several cancers, driving both cell proliferation and metastasis $[57,58]$. Activation of the Wnt pathway results in liberation of $\beta$-catenin from a cytoplasmic inhibitory complex, enabling it to translocate to the nucleus and bind to TCF, recruit transcriptional co-activators and stimulate expression of Wnt target genes. Numerous reports have demonstrated that SOX proteins positively (e.g. SOX2 and SOX4 in breast and colon cancers, respectively) or negatively (e.g. SOX9, SOX7, and SOX17 in colorectal cancer) regulate Wnt-mediated transcriptional activity through a variety of mechanisms, including: binding with $\beta$-catenin to prevent TCF from interacting with $\beta$-catenin, interacting with TCFs directly to inhibit them from binding $\beta$-catenin, competitive binding with TCF proteins for DNA sites, recruitment of transcriptional repressors or activators, stabilization of TCF repression, or promotion of $\beta$-catenin degradation [59, 60]. Interestingly, some SOX members (e.g. SOX21 and $S O X 9$ ) have also been implicated in non-canonical Wnt signaling due to their modulation of planar cell polarity signaling (PCP), which is known to contribute to tumor progression and metastasis [61-64]. Work exploring the involvement of SOX proteins in cancer through their effects on PCP may provide additional insights into how SOX disruption promotes aggressive tumor phenotypes.

In addition to the $\mathrm{Wnt} / \beta$-catenin pathway, SOX family members also have established roles in other developmental pathways including the Notch, Sonic Hedgehog, and Hippo pathways [5, 7, 65-68]. SOX genes can affect these pathways at both upstream (i.e. 
pathway stimulation) and downstream (i.e. transcriptional activity) levels, through transcriptional regulation of genes encoding pathway proteins or target genes, respectively. Figure 2 demonstrates known interactions between SOX proteins and developmental pathways implicated in carcinogenesis. SOX1 exhibits downstream regulation of the Notch pathway in neural progenitor cells by binding to the gene promoter of the HES1 transcription factor, repressing its transcription, thereby mitigating Notch signaling and promoting neuronal differentiation [69]. In contrast, through its transcriptional activation of HES1, SOX1 is involved in promoting the switch from neurogenesis to gliogenesis in the ventral spinal cord [70]. In the Hedgehog pathway, SOX9 and SOX2 partner with GLI transcription factors, the downstream effectors of Hedgehog signaling to activate expression of transcription factors required for cartilage development and spinal cord neural progenitor cells, respectively [65-67]. A similar example is evident in the regulation of organogenesis via the Hippo pathway, where SOXC factors (SOX4, SOX11, and SOX12) control the expression of the transcriptional mediator of the pathway, TEAD2 [71]. In the brain, SOX2 regulates the expression of sonic hedgehog $(\mathrm{SHH})$, whose corresponding protein stimulates the Hedgehog signaling cascade; this example of upstream regulation is important for stem cell maintenance in brain development [72].

\section{Discovery of $S O X 15$ as a potential tumor suppressor in pancreatic cancer}

We recently identified SOX15 (also known as $S O X 20)$ as a potential tumor suppressor gene negatively associated with the $\mathrm{Wnt} / \beta$-catenin pathway in pancreatic ductal adenocarcinoma (PDAC) [45]. A multi-dimensional, integrative genomic analysis of 20 PDAC cell lines revealed SOX15 was inactivated as a result of multiple molecular mechanisms. We observed recurrent two-hit inactivation, defined as concurrent copy number loss and DNA hypermethylation associated with underexpression within an individual sample, in $45 \%$ of the cell lines assessed. Our observation of

A. Downstream activation and repression of targets of the Wnt pathway

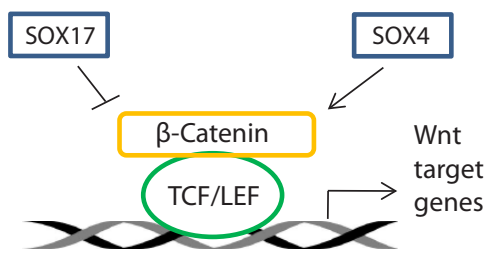

B. Upstream and downstream regulation of Hedgehog signaling through regulation of Shh and Hedgehog target genes

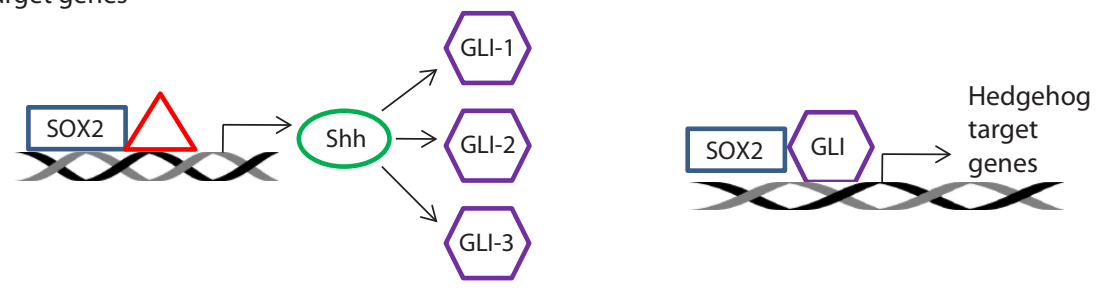

C. Transcriptional regulation of effector transcription factors of the Notch and Hippo pathways

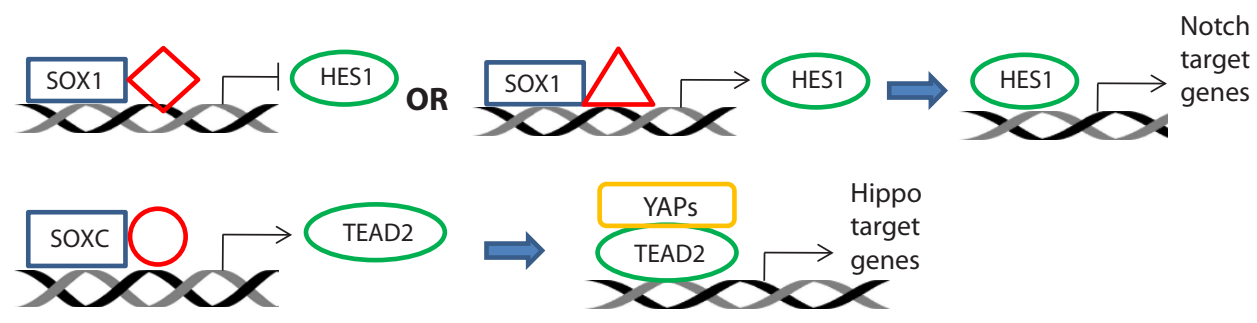

Figure 2: Involvement of SOX proteins in various developmental pathways that have been associated with tumorigenesis. SOX members are involved in regulating several signaling pathways relevant to tumorigenesis, including the Wnt, Hedgehog, Notch, and Hippo pathways. (A) In the Wnt pathway, SOX proteins can bind $\beta$-catenin or TCF/LEF to either promote or suppress Wnt mediated transcriptional activity. (B) In the Hedgehog pathway, SOX proteins act upstream to control the expression of sonic hedgehog (Shh) and downstream through interaction with GLI to promote transcription of pathway target genes. (C) In the Notch and Hippo pathways, SOX proteins bind with other factors to control expression of their transcription factor effectors, HES1 and TEAD2, respectively. 
SOX15 disruption was consistent with Knudson's two-hit hypothesis for tumor suppressor gene inactivation [73]. Following validation of $S O X 15$ downregulation in clinical PDAC tumors, we performed experiments demonstrating that SOX15 exerts tumor suppressor properties in vitro and in vivo. Specifically, re-expression of SOX15 in PDAC lines with undetectable endogenous levels resulted in significantly reduced cell viability and tumor growth [45]. To deduce a potential mechanism through which SOX15 may exert its tumor suppressive effects, we turned our attention to the Wnt pathway since other SOX family members are known to regulate $\mathrm{Wnt} / \beta$-catenin signaling and our pathway analysis suggested a potential role for SOX15 in this pathway. Multiple different assays revealed that SOX15 expression was associated with a modest but consistent reduction in Wnt pathway activity. Taken together, our findings provide novel evidence of the involvement of yet another SOX family member in the process of carcinogenesis.

\section{The role of $S O X 15$ in developmental and cancer biology}

The role of SOX15 in cell biology and development is relatively understudied compared to other $S O X$ family members, such as $S O X 2, S O X 4$ and $S O X 9$. Early work demonstrated $S O X 15$ expression in fetal brain, spinal cord, thymus, heart and adrenal tissues as well as in adult brain,

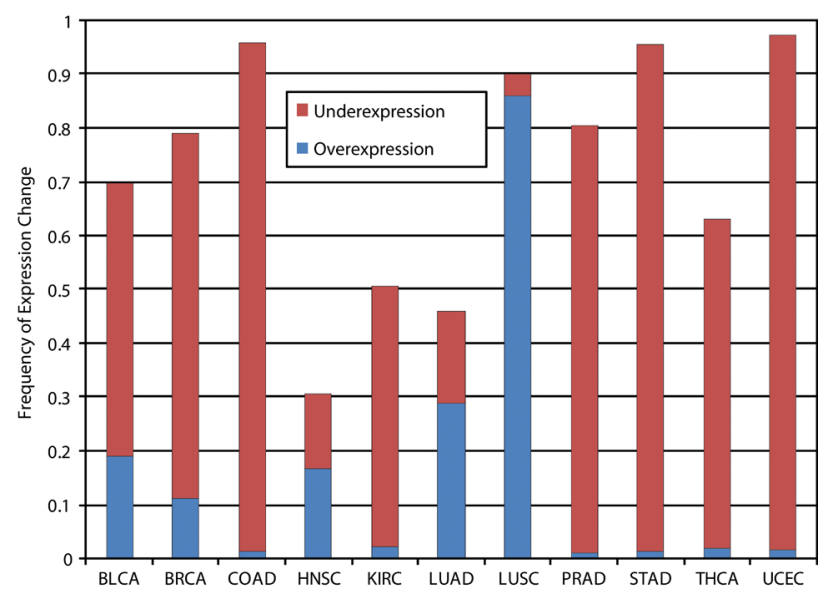

Figure 3: SOX15 expression status in various cancer types. Frequency of SOX15 over- and underexpression in 11 cancertypes, illustrating SOX15 is predominantly underexpressed in cancer with the exception of lung adenocarcinoma (LUAD) and squamous cell carcinoma (LUSC), in which it is frequently overexpressed. Cancer types are annotated as follows: BLCA bladder urothelial carcinoma; BRCA - breast invasive carcinoma; COAD - colon adenocarcinoma; HNSC - head and neck squamous cell carcinoma; KIRC - kidney clear cell carcinoma; LUAD - lung adenocarcinoma; LUSC - lung squamous cell carcinoma; PRAD - prostate adenocarcinoma; STAD - stomach adenocarcinoma; THCA - thyroid carcinoma; UCEC - uterine corpus endometrioid carcinoma. lung, heart, liver, spleen, gut, small intestine, kidney, and testes tissues [74]. Knockout studies revealed that SOX15-null mice and embryonic stem cells are viable and grossly normal, perhaps suggesting functional redundancy with other $S O X$ members [5, 7, 75, 76]. However, manipulation of $S O X 15$ levels in mice results in muscular abnormalities, implicating SOX15 in the regulation of skeletal muscle development [75, 77-79]. More recent studies have suggested that $S O X 15$ is a potential mediator of pluripotency and stemness due to its upregulation in induced pluripotent and embryonic stem cells and mesodermal progenitor cells [80,81].

In cancer, SOX15 overexpression was found to inhibit the proliferation of human testicular embryonic carcinoma cells [82]. This negative regulation of cancer cell proliferation is consistent with our results of $S O X 15$ expression reducing tumor growth, providing additional evidence of a potential suppressor role for SOX15 in tumorigenesis. Further supporting this concept, our pancancer analysis of SOX15 gene expression showed it was recurrently downregulated in multiple cancer types with high frequencies of disruption ( $\geq 80 \%$ ), including colon, stomach, prostate, and uterine cancers (Figure 3). In contrast, SOX15 appeared to be frequently overexpressed in lung adenocarcinoma and squamous cell carcinoma, potentially exemplifying the tissue-specific dependency of SOX gene expression and function (Figure 3). Collectively, our pan-cancer expression analysis and functional validation of SOX15 in PDAC, suggests that SOX15 may be involved in multiple cancer types.

\section{SOX15: Where do we go from here?}

Much remains to be learned about SOX15 function in development, cell differentiation, and cancer. While we demonstrated a role for SOX15 in regulation of the Wnt/ $\beta$-catenin pathway in PDAC, we acknowledge that the moderate suppression of Wnt activity does not reflect the large effect SOX15 expression had on inhibition of tumor growth, suggesting SOX15 may function through additional cellular pathways to mediate its inhibitory effect [45]. Moreover, since many SOX members have various roles in different cellular programs, it is possible that SOX15 is involved in normal biological processes other than just muscle development $[5,7]$. We suggest three key avenues of research should be undertaken to elucidate novel roles of SOX15 in cell and developmental biology; these include identification of SOX15 transcriptional targets, understanding SOX15 expression patterns and transcriptional regulation, and identification of protein interacting partners.

Perhaps the most informative strategy for identifying novel SOX15 functions is to determine what genes it regulates (i.e. SOX15 target genes), appreciating that this may be cell-and tissue-dependent. A similar approach was recently used to infer the biological functions of SOX11 
in mantle cell lymphoma and SOX2 in glioblastoma multiforme [83, 84]. SOX15 target genes could be revealed using a combination of approaches such as chromatin immunoprecipitation coupled with sequencing (ChIP-seq) to identify SOX15 DNA binding sites, and/or, genome wide expression profiling following manipulation of SOX15 levels to identify genes whose expression is strongly correlated to that of SOX15. We employed the latter approach to find cellular pathways associated with SOX15 in our PDAC study, and identified the Wnt and ERK5 signaling pathways as candidates for SOX15 regulation [45]. Although findings from genome wide approaches must be validated, they provide an excellent starting point for the identification of novel target genes.

Determining the spatial and temporal patterns of SOX15 expression throughout development will be extremely informative for identifying roles of SOX15 in developmental biology. Mapping of protein expression throughout mouse organogenesis provided insights into the role of SOX13 in multiple developmental processes, and this approach is a logical next step to further our understanding of SOX15 function [85]. Moreover, deciphering how $S O X 15$ is transcriptionally regulated and understanding what cellular pathways or signals activate SOX15 gene expression could also reveal novel insights into its function. Evidence suggests that SOX gene expression can be controlled autonomously by other SOX factors, or regulated epigenetically, for example through DNA methylation or micro-RNA (miRNA) expression [5, $15,17,45,80,86,87]$; thus, knowing the biological roles of miRNAs governing $S O X 15$ expression could possibly shed light on SOX15 function. We also do not overlook the possibility that post-translational modifications may play an important role in mediating SOX15 behavior, as has been observed for SOX2 [5].

Lastly, it is well documented that the activity of SOX transcription factors is highly dependent on the proteins they partner with to exert their effects $[88,89]$. SOX proteins may bind with completely different proteins or other SOX members. SOXB1/C/F members bind to heterologous transcription factors; for example, SOX2 partners with OCT4 (also known as POU5F1) to maintain embryonic stem cell pluripotency [90]. On the other hand, SOX5 and SOX6 can dimerize and this binding enhances their ability to bind DNA $[88,91]$. The finding of SOX proteins binding downstream protein components of the Wnt pathway (e.g. TCF or $\beta$-catenin) would implicate their involvement in Wnt signaling. Thus, clues about SOX15 function could come from discerning its protein binding partners using a variety of high throughput proteomic or immunoprecipitation strategies.

\section{CONCLUSIONS}

The reports of SOX transcription factors in the literature emphasize the critical roles $S O X$ genes play in developmental and cancer biology. While some SOX proteins are well studied, we have barely scratched the surface in understanding the biological functions of many others, especially in the context of malignancy. Nevertheless, due to their regulation of stemness, pluripotency, developmental pathways, and numerous cancer processes, it is clear that $S O X$ members are integral contributors to cancer biology. We have provided a snapshot of $S O X$ deregulation in a variety of cancer types, revealing that $S O X$ expression patterns are broadly, aberrantly expressed in cancer, heightening interest in several SOX members that are recurrently disrupted but have not yet been studied in carcinogenesis. We also summarized our recent finding of the relatively understudied SOX member, SOX15, as a potential tumor suppressor gene frequently inactivated in pancreatic cancer. Further work to study this gene in different cancer types and to elucidate additional mechanisms through which it may function is required to gain a better understanding of SOX15's physiological role in normal and diseased states, and could lead to the development of novel cancer therapeutic strategies [2].

\section{Conflicts of Interest}

The authors have no conflicts of interest to declare.

\section{ACKNOWLEDGEMENTS}

The pan-cancer SOX gene expression results presented here are based upon data generated by the TCGA Research Network (http://cancergenome.nih.gov/). The authors would like to thank Dr. Victor Martinez for assisting with data acquisition and visualization. This work was supported by grants from the Canadian Institutes for Health Research, Canadian Cancer Society Research Institute, Terry Fox Foundation, PMH Foundation, Ontario Ministry of Health and Long Term Care, and Vanier Canada Graduate Scholarships to KLT, DDBS, NR and LAP. MST is the M Qasim Choksi Chair in Lung Cancer Translational Research.

\section{REFERENCES}

1. Dong C, Wilhelm D and Koopman P. Sox genes and cancer. Cytogenetic and genome research. 2004; 105(2-4):442-447.

2. Castillo SD and Sanchez-Cespedes M. The SOX family of genes in cancer development: biological relevance and opportunities for therapy. Expert opinion on therapeutic targets. 2012; 16(9):903-919.

3. Gubbay J, Collignon J, Koopman P, Capel B, Economou A, Munsterberg A, Vivian N, Goodfellow P and LovellBadge R. A gene mapping to the sex-determining region of the mouse $\mathrm{Y}$ chromosome is a member of a novel family of embryonically expressed genes. Nature. 1990; 
346(6281):245-250.

4. Bowles J, Schepers G and Koopman P. Phylogeny of the SOX family of developmental transcription factors based on sequence and structural indicators. Developmental biology. 2000; 227(2):239-255.

5. Kamachi $Y$ and Kondoh H. Sox proteins: regulators of cell fate specification and differentiation. Development. 2013; 140(20):4129-4144.

6. Wegner M. All purpose Sox: The many roles of Sox proteins in gene expression. The international journal of biochemistry \& cell biology. 2010; 42(3):381-390.

7. Sarkar A and Hochedlinger K. The sox family of transcription factors: versatile regulators of stem and progenitor cell fate. Cell stem cell. 2013; 12(1):15-30.

8. Zhu Y, Li Y, Jun Wei JW and Liu X. The role of sox genes in lung morphogenesis and cancer. International journal of molecular sciences. 2012; 13(12):15767-15783.

9. Vervoort SJ, van Boxtel R and Coffer PJ. The role of SRY-related HMG box transcription factor 4 (SOX4) in tumorigenesis and metastasis: friend or foe? Oncogene. 2013; 32(29):3397-3409.

10. Rudin CM, Durinck S, Stawiski EW, Poirier JT, Modrusan Z, Shames DS, Bergbower EA, Guan Y, Shin J, Guillory J, Rivers CS, Foo CK, Bhatt D, Stinson J, Gnad F, Haverty $\mathrm{PM}$, et al. Comprehensive genomic analysis identifies SOX2 as a frequently amplified gene in small-cell lung cancer. Nature genetics. 2012; 44(10):1111-1116.

11. Bass AJ, Watanabe H, Mermel CH, Yu S, Perner S, Verhaak RG, Kim SY, Wardwell L, Tamayo P, Gat-Viks I, Ramos AH, Woo MS, Weir BA, Getz G, Beroukhim R, O'Kelly $\mathrm{M}$, et al. SOX2 is an amplified lineage-survival oncogene in lung and esophageal squamous cell carcinomas. Nature genetics. 2009; 41(11):1238-1242.

12. Wang L, He S, Yuan J, Mao X, Cao Y, Zong J, Tu Y and Zhang Y. Oncogenic role of SOX9 expression in human malignant glioma. Med Oncol. 2012; 29(5):3484-3490.

13. Kopp JL, von Figura G, Mayes E, Liu FF, Dubois CL, Morris JPt, Pan FC, Akiyama H, Wright CV, Jensen K, Hebrok M and Sander M. Identification of Sox9-dependent acinar-to-ductal reprogramming as the principal mechanism for initiation of pancreatic ductal adenocarcinoma. Cancer cell. 2012; 22(6):737-750.

14. Matheu A, Collado M, Wise C, Manterola L, Cekaite L, Tye AJ, Canamero M, Bujanda L, Schedl A, Cheah KS, Skotheim RI, Lothe RA, Lopez de Munain A, Briscoe J, Serrano M and Lovell-Badge R. Oncogenicity of the developmental transcription factor Sox9. Cancer research. 2012; 72(5):1301-1315.

15. Stovall DB, Wan M, Miller LD, Cao P, Maglic D, Zhang Q, Stampfer MR, Liu W, Xu J and Sui G. The regulation of SOX7 and its tumor suppressive role in breast cancer. The American journal of pathology. 2013; 183(5):1645-1653.

16. Stovall DB, Cao P and Sui G. SOX7: From a developmental regulator to an emerging tumor suppressor. Histology and histopathology. 2014; 29(4):439-445.

17. Otsubo T, Akiyama Y, Yanagihara K and Yuasa Y. SOX2 is frequently downregulated in gastric cancers and inhibits cell growth through cell-cycle arrest and apoptosis. British journal of cancer. 2008; 98(4):824-831.

18. Passeron T, Valencia JC, Namiki T, Vieira WD, Passeron $\mathrm{H}$, Miyamura Y and Hearing VJ. Upregulation of SOX9 inhibits the growth of human and mouse melanomas and restores their sensitivity to retinoic acid. The Journal of clinical investigation. 2009; 119(4):954-963.

19. Ordonez NG. Value of SOX10 immunostaining in tumor diagnosis. Advances in anatomic pathology. 2013; 20(4):275-283.

20. Chen QL, Zheng WL, Yao WJ, Nie LW, Cheng SH and Ma WL. Analysis of SOX4 gene mutation in non-small cell lung cancer tissues. Zhonghua yi xue yi chuan xue za zhi $=$ Zhonghua yixue yichuanxue zazhi $=$ Chinese journal of medical genetics. 2007; 24(5):505-509.

21. Yin D, Jia Y, Yu Y, Brock MV, Herman JG, Han C, Su X, Liu Y and Guo M. SOX17 methylation inhibits its antagonism of Wnt signaling pathway in lung cancer. Discovery medicine. 2012; 14(74):33-40.

22. Sun M, Uozaki H, Hino R, Kunita A, Shinozaki A, Ushiku T, Hibiya T, Takeshita K, Isogai M, Takada K and Fukayama M. SOX9 expression and its methylation status in gastric cancer. Virchows Archiv : an international journal of pathology. 2012; 460(3):271-279.

23. Cox JL, Wilder PJ, Desler M and Rizzino A. Elevating SOX2 levels deleteriously affects the growth of medulloblastoma and glioblastoma cells. PloS one. 2012; 7(8):e44087.

24. Swartling FJ, Savov V, Persson AI, Chen J, Hackett CS, Northcott PA, Grimmer MR, Lau J, Chesler L, Perry A, Phillips JJ, Taylor MD and Weiss WA. Distinct neural stem cell populations give rise to disparate brain tumors in response to N-MYC. Cancer cell. 2012; 21(5):601-613.

25. Burgos-Ojeda D, Rueda BR and Buckanovich RJ. Ovarian cancer stem cell markers: prognostic and therapeutic implications. Cancer letters. 2012; 322(1):1-7.

26. Jiang SS, Fang WT, Hou YH, Huang SF, Yen BL, Chang JL, Li SM, Liu HP, Liu YL, Huang CT, Li YW, Jang TH, Chan SH, Yang SJ, Hsiung CA, Wu CW, et al. Upregulation of SOX9 in lung adenocarcinoma and its involvement in the regulation of cell growth and tumorigenicity. Clinical cancer research : an official journal of the American Association for Cancer Research. 2010; 16(17):4363-4373.

27. Li B, Ge Z, Song S, Zhang S, Yan H, Huang B and Zhang Y. Decreased expression of SOX7 is correlated with poor prognosis in lung adenocarcinoma patients. Pathology oncology research : POR. 2012; 18(4):1039-1045.

28. Sholl LM, Barletta JA, Yeap BY, Chirieac LR and Hornick JL. Sox2 protein expression is an independent poor prognostic indicator in stage I lung adenocarcinoma. The American journal of surgical pathology. 2010; 34(8):1193- 
1198.

29. Yousem SA. Role of molecular studies in the diagnosis of lung adenocarcinoma. Modern pathology : an official journal of the United States and Canadian Academy of Pathology, Inc. 2012; 25 Suppl 1:S11-17.

30. Guo X, Xiong L, Sun T, Peng R, Zou L, Zhu H, Zhang J, Li $\mathrm{H}$ and Zhao J. Expression features of SOX9 associate with tumor progression and poor prognosis of hepatocellular carcinoma. Diagnostic pathology. 2012; 7:44.

31. Chen Y, Shi L, Zhang L, Li R, Liang J, Yu W, Sun L, Yang X, Wang Y, Zhang Y and Shang Y. The molecular mechanism governing the oncogenic potential of SOX2 in breast cancer. The Journal of biological chemistry. 2008; 283(26):17969-17978.

32. Fu DY, Wang ZM, Li C, Wang BL, Shen ZZ, Huang W and Shao ZM. Sox17, the canonical Wnt antagonist, is epigenetically inactivated by promoter methylation in human breast cancer. Breast cancer research and treatment. 2010; 119(3):601-612.

33. Acloque H, Ocana OH, Matheu A, Rizzoti K, Wise C, Lovell-Badge $\mathrm{R}$ and Nieto MA. Reciprocal repression between Sox3 and snail transcription factors defines embryonic territories at gastrulation. Developmental cell. 2011; 21(3):546-558.

34. Liu P, Ramachandran S, Ali Seyed M, Scharer CD, Laycock N, Dalton WB, Williams H, Karanam S, Datta MW, Jaye $\mathrm{DL}$ and Moreno CS. Sex-determining region $\mathrm{Y}$ box 4 is a transforming oncogene in human prostate cancer cells. Cancer research. 2006; 66(8):4011-4019.

35. Scharer CD, McCabe CD, Ali-Seyed M, Berger MF, Bulyk $\mathrm{ML}$ and Moreno CS. Genome-wide promoter analysis of the SOX4 transcriptional network in prostate cancer cells. Cancer research. 2009; 69(2):709-717.

36. Wang H, McKnight NC, Zhang T, Lu ML, Balk SP and Yuan X. SOX9 is expressed in normal prostate basal cells and regulates androgen receptor expression in prostate cancer cells. Cancer research. 2007; 67(2):528-536.

37. Zhong WD, Qin GQ, Dai QS, Han ZD, Chen SM, Ling XH, $\mathrm{Fu}$ X, Cai C, Chen JH, Chen XB, Lin ZY, Deng YH, Wu $\mathrm{SL}, \mathrm{He} \mathrm{HC}$ and Wu CL. SOXs in human prostate cancer: implication as progression and prognosis factors. BMC cancer. 2012; 12:248.

38. Sinner D, Kordich JJ, Spence JR, Opoka R, Rankin S, Lin SC, Jonatan D, Zorn AM and Wells JM. Sox17 and Sox4 differentially regulate beta-catenin/T-cell factor activity and proliferation of colon carcinoma cells. Molecular and cellular biology. 2007; 27(22):7802-7815.

39. Azhikina T, Kozlova A, Skvortsov T and Sverdlov E. Heterogeneity and degree of TIMP4, GATA4, SOX18, and EGFL7 gene promoter methylation in non-small cell lung cancer and surrounding tissues. Cancer genetics. 2011; 204(9):492-500.

40. Castillo SD, Matheu A, Mariani N, Carretero J, LopezRios F, Lovell-Badge R and Sanchez-Cespedes M. Novel transcriptional targets of the SRY-HMG box transcription factor SOX4 link its expression to the development of small cell lung cancer. Cancer research. 2012; 72(1):176-186.

41. Chen S, Xu Y, Chen Y, Li X, Mou W, Wang L, Liu Y, Reisfeld RA, Xiang R, Lv D and Li N. SOX2 gene regulates the transcriptional network of oncogenes and affects tumorigenesis of human lung cancer cells. PloS one. 2012; 7(5):e36326.

42. Li X, Wang J, Xu Z, Ahmad A, Li E, Wang Y, Qin S and Wang Q. Expression of sox2 and oct4 and their clinical significance in human non-small-cell lung cancer. International journal of molecular sciences. 2012; 13(6):7663-7675.

43. Maddison P, Thorpe A, Silcocks P, Robertson JF and Chapman CJ. Autoimmunity to SOX2, clinical phenotype and survival in patients with small-cell lung cancer. Lung Cancer. 2010; 70(3):335-339.

44. Medina PP, Castillo SD, Blanco S, Sanz-Garcia M, Largo C, Alvarez S, Yokota J, Gonzalez-Neira A, Benitez J, Clevers HC, Cigudosa JC, Lazo PA and Sanchez-Cespedes M. The SRY-HMG box gene, SOX4, is a target of gene amplification at chromosome $6 \mathrm{p}$ in lung cancer. Human molecular genetics. 2009; 18(7):1343-1352.

45. Thu KL, Radulovich N, Becker-Santos DD, Pikor LA, Pusic A, Lockwood WW, Lam WL and Tsao MS. SOX15 is a candidate tumor suppressor in pancreatic cancer with a potential role in $\mathrm{Wnt} /$ beta-catenin signaling. Oncogene. 2014; 33(3):279-288.

46. Titulaer MJ, Klooster R, Potman M, Sabater L, Graus F, Hegeman IM, Thijssen PE, Wirtz PW, Twijnstra A, Smitt PA, van der Maarel SM and Verschuuren JJ. SOX antibodies in small-cell lung cancer and Lambert-Eaton myasthenic syndrome: frequency and relation with survival. Journal of clinical oncology : official journal of the American Society of Clinical Oncology. 2009; 27(26):42604267.

47. Wilbertz T, Wagner P, Petersen K, Stiedl AC, Scheble VJ, Maier S, Reischl M, Mikut R, Altorki NK, Moch H, Fend F, Staebler A, Bass AJ, Meyerson M, Rubin MA, Soltermann A, et al. SOX2 gene amplification and protein overexpression are associated with better outcome in squamous cell lung cancer. Modern pathology : an official journal of the United States and Canadian Academy of Pathology, Inc. 2011; 24(7):944-953.

48. Xiang R, Liao D, Cheng T, Zhou H, Shi Q, Chuang TS, Markowitz D, Reisfeld RA and Luo Y. Downregulation of transcription factor SOX2 in cancer stem cells suppresses growth and metastasis of lung cancer. British journal of cancer. 2011; 104(9):1410-1417.

49. Lin YW, Tsao CM, Yu PN, Shih YL, Lin CH and Yan MD. SOX1 suppresses cell growth and invasion in cervical cancer. Gynecologic oncology. 2013; 131(1):174-181.

50. Choi YJ, Song JH, Yoon JH, Choi WS, Nam SW, Lee JY and Park WS. Aberrant expression of SOX9 is associated with gastrokine 1 inactivation in gastric cancers. Gastric 
cancer : official journal of the International Gastric Cancer Association and the Japanese Gastric Cancer Association. 2014; 17(2):247-254.

51. Hayano T, Garg M, Yin D, Sudo M, Kawamata N, Shi S, Chien W, Ding LW, Leong G, Mori S, Xie D, Tan P and Koeffler HP. SOX7 is down-regulated in lung cancer. Journal of experimental \& clinical cancer research : CR. 2013; 32:17.

52. Shivane A, Parkinson DB, Ammoun S and Hanemann CO. Expression of c-Jun and Sox-2 in human schwannomas and traumatic neuromas. Histopathology. 2013; 62(4):651-656.

53. Zhang S, Zhu C, Zhu L, Liu H, Liu S, Zhao N, Wu J, Huang X, Zhang Y, Jin J, Ji T and Ding X. Oncogenicity of the transcription factor SOX8 in hepatocellular carcinoma. Med Oncol. 2014; 31(4):918.

54. Naujokas A, Charli-Joseph Y, Ruben BS, Yeh I, LeBoit PE, McCalmont TH and Pincus LB. SOX-10 expression in cutaneous myoepitheliomas and mixed tumors. Journal of cutaneous pathology. 2014; 41(4):353-363.

55. Uhlen M, Oksvold P, Fagerberg L, Lundberg E, Jonasson K, Forsberg M, Zwahlen M, Kampf C, Wester K, Hober $\mathrm{S}$, Wernerus $\mathrm{H}$, Bjorling $\mathrm{L}$ and Ponten F. Towards a knowledge-based Human Protein Atlas. Nature biotechnology. 2010; 28(12):1248-1250.

56. Hanahan D and Weinberg RA. Hallmarks of cancer: the next generation. Cell. 2011; 144(5):646-674.

57. Polakis P. Wnt signaling in cancer. Cold Spring Harbor perspectives in biology. 2012; 4(5).

58. Anastas JN and Moon RT. WNT signalling pathways as therapeutic targets in cancer. Nature reviews Cancer. 2013; 13(1):11-26.

59. Bernard P and Harley VR. Acquisition of SOX transcription factor specificity through protein-protein interaction, modulation of Wnt signalling and post-translational modification. The international journal of biochemistry \& cell biology. 2010; 42(3):400-410.

60. Kormish JD, Sinner D and Zorn AM. Interactions between SOX factors and Wnt/beta-catenin signaling in development and disease. Developmental dynamics : an official publication of the American Association of Anatomists. 2010; 239(1):56-68.

61. Jessen JR. Noncanonical Wnt signaling in tumor progression and metastasis. Zebrafish. 2009; 6(1):21-28.

62. Wang Y. Wnt/Planar cell polarity signaling: a new paradigm for cancer therapy. Molecular cancer therapeutics. 2009; 8(8):2103-2109.

63. Hosoya M, Fujioka M, Matsuda S, Ohba H, Shibata S, Nakagawa F, Watabe T, Wakabayashi K, Saga Y, Ogawa $\mathrm{K}$, Okano HJ and Okano H. Expression and function of Sox 21 during mouse cochlea development. Neurochemical research. 2011; 36(7):1261-1269.

64. Darido C, Buchert M, Pannequin J, Bastide P, Zalzali H, Mantamadiotis T, Bourgaux JF, Garambois V, Jay P, Blache P, Joubert D and Hollande F. Defective claudin-7 regulation by Tef-4 and Sox-9 disrupts the polarity and increases the tumorigenicity of colorectal cancer cells. Cancer research. 2008; 68(11):4258-4268.

65. Leung VY, Gao B, Leung KK, Melhado IG, Wynn SL, Au TY, Dung NW, Lau JY, Mak AC, Chan D and Cheah KS. SOX9 governs differentiation stage-specific gene expression in growth plate chondrocytes via direct concomitant transactivation and repression. PLoS genetics. 2011; 7(11):e1002356.

66. Oosterveen T, Kurdija S, Alekseenko Z, Uhde CW, Bergsland M, Sandberg M, Andersson E, Dias JM, Muhr J and Ericson J. Mechanistic differences in the transcriptional interpretation of local and long-range Shh morphogen signaling. Developmental cell. 2012; 23(5):1006-1019.

67. Peterson KA, Nishi Y, Ma W, Vedenko A, Shokri L, Zhang X, McFarlane M, Baizabal JM, Junker JP, van Oudenaarden A, Mikkelsen T, Bernstein BE, Bailey TL, Bulyk ML, Wong WH and McMahon AP. Neural-specific Sox2 input and differential Gli-binding affinity provide context and positional information in Shh-directed neural patterning. Genes \& development. 2012; 26(24):2802-2816.

68. Corada M, Orsenigo F, Morini MF, Pitulescu ME, Bhat G, Nyqvist D, Breviario F, Conti V, Briot A, Iruela-Arispe ML, Adams RH and Dejana E. Sox17 is indispensable for acquisition and maintenance of arterial identity. Nature communications. 2013; 4:2609.

69. Kan L, Israsena N, Zhang Z, Hu M, Zhao LR, Jalali A, Sahni $\mathrm{V}$ and Kessler JA. Sox 1 acts through multiple independent pathways to promote neurogenesis. Developmental biology. 2004; 269(2):580-594.

70. Genethliou N, Panayiotou E, Panayi H, Orford M, Mean R, Lapathitis G, Gill H, Raoof S, De Gasperi R, Elder G, Kessaris N, Richardson WD and Malas S. SOX1 links the function of neural patterning and Notch signalling in the ventral spinal cord during the neuron-glial fate switch. Biochemical and biophysical research communications. 2009; 390(4):1114-1120.

71. Bhattaram P, Penzo-Mendez A, Sock E, Colmenares C, Kaneko KJ, Vassilev A, Depamphilis ML, Wegner M and Lefebvre V. Organogenesis relies on SoxC transcription factors for the survival of neural and mesenchymal progenitors. Nature communications. 2010; 1:9.

72. Favaro R, Valotta M, Ferri AL, Latorre E, Mariani J, Giachino C, Lancini C, Tosetti V, Ottolenghi S, Taylor V and Nicolis SK. Hippocampal development and neural stem cell maintenance require Sox2-dependent regulation of Shh. Nature neuroscience. 2009; 12(10):1248-1256.

73. Berger AH, Knudson AG and Pandolfi PP. A continuum model for tumour suppression. Nature. 2011; 476(7359):163-169.

74. Vujic M, Rajic T, Goodfellow PN and Stevanovic M. cDNA characterization and high resolution mapping of the human SOX20 gene. Mammalian genome : official journal of the International Mammalian Genome Society. 1998; 9(12):1059-1061. 
75. Lee HJ, Goring W, Ochs M, Muhlfeld C, Steding G, Paprotta I, Engel W and Adham IM. Sox15 is required for skeletal muscle regeneration. Molecular and cellular biology. 2004; 24(19):8428-8436.

76. Maruyama M, Ichisaka T, Nakagawa $M$ and Yamanaka S. Differential roles for Sox 15 and Sox 2 in transcriptional control in mouse embryonic stem cells. The Journal of biological chemistry. 2005; 280(26):24371-24379.

77. Beranger F, Mejean C, Moniot B, Berta P and Vandromme M. Muscle differentiation is antagonized by SOX15, a new member of the SOX protein family. The Journal of biological chemistry. 2000; 275(21):16103-16109.

78. Meeson AP, Shi X, Alexander MS, Williams RS, Allen RE, Jiang N, Adham IM, Goetsch SC, Hammer RE and Garry DJ. Sox 15 and Fhl3 transcriptionally coactivate Foxk1 and regulate myogenic progenitor cells. The EMBO journal. 2007; 26(7):1902-1912.

79. Savage J, Conley AJ, Blais A and Skerjanc IS. SOX15 and SOX7 differentially regulate the myogenic program in P19 cells. Stem Cells. 2009; 27(6):1231-1243.

80. Nishino K, Toyoda M, Yamazaki-Inoue M, Makino H, Fukawatase Y, Chikazawa E, Takahashi Y, Miyagawa Y, Okita H, Kiyokawa N, Akutsu H and Umezawa A. Defining hypo-methylated regions of stem cell-specific promoters in human iPS cells derived from extra-embryonic amnions and lung fibroblasts. PloS one. 2010; 5(9):e13017.

81. Pacini S, Carnicelli V, Trombi L, Montali M, Fazzi R, Lazzarini E, Giannotti S and Petrini M. Constitutive expression of pluripotency-associated genes in mesodermal progenitor cells (MPCs). PloS one. 2010; 5(3):e9861.

82. Yan HT, Shinka T, Sato Y, Yang XJ, Chen G, Sakamoto K, Kinoshita K, Aburatani $\mathrm{H}$ and Nakahori Y. Overexpression of SOX15 inhibits proliferation of NT2/D1 cells derived from a testicular embryonal cell carcinoma. Molecules and cells. 2007; 24(3):323-328.

83. Vegliante MC, Palomero J, Perez-Galan P, Roue G, Castellano G, Navarro A, Clot G, Moros A, SuarezCisneros H, Bea S, Hernandez L, Enjuanes A, Jares P, Villamor N, Colomer D, Martin-Subero JI, et al. SOX11 regulates PAX5 expression and blocks terminal B-cell differentiation in aggressive mantle cell lymphoma. Blood. 2013; 121(12):2175-2185.

84. Fang X, Yoon JG, Li L, Yu W, Shao J, Hua D, Zheng S, Hood L, Goodlett DR, Foltz G and Lin B. The SOX2 response program in glioblastoma multiforme: an integrated ChIP-seq, expression microarray, and microRNA analysis. BMC genomics. 2011; 12:11.

85. Wang Y, Ristevski S and Harley VR. SOX13 exhibits a distinct spatial and temporal expression pattern during chondrogenesis, neurogenesis, and limb development. The journal of histochemistry and cytochemistry : official journal of the Histochemistry Society. 2006; 54(12):13271333.

86. Biswal BK, Beyrouthy MJ, Hever-Jardine MP, Armstrong
D, Tomlinson CR, Christensen BC, Marsit CJ and Spinella MJ. Acute hypersensitivity of pluripotent testicular cancer-derived embryonal carcinoma to low-dose 5-aza deoxycytidine is associated with global DNA Damageassociated p53 activation, anti-pluripotency and DNA demethylation. PloS one. 2012; 7(12):e53003.

87. Xu N, Papagiannakopoulos T, Pan G, Thomson JA and Kosik KS. MicroRNA-145 regulates OCT4, SOX2, and KLF4 and represses pluripotency in human embryonic stem cells. Cell. 2009; 137(4):647-658.

88. Kamachi Y, Uchikawa M and Kondoh H. Pairing SOX off: with partners in the regulation of embryonic development. Trends in genetics : TIG. 2000; 16(4):182-187.

89. Kondoh $\mathrm{H}$ and Kamachi Y. SOX-partner code for cell specification: Regulatory target selection and underlying molecular mechanisms. The international journal of biochemistry \& cell biology. 2010; 42(3):391-399.

90. Chambers I and Tomlinson SR. The transcriptional foundation of pluripotency. Development. 2009; 136(14):2311-2322.

91. Lefebvre V, Li P and de Crombrugghe B. A new long form of Sox5 (L-Sox5), Sox6 and Sox9 are coexpressed in chondrogenesis and cooperatively activate the type II collagen gene. The EMBO journal. 1998; 17(19):57185733.

92. Goldman M, Craft B, Swatloski T, Ellrott K, Cline M, Diekhans M, Ma S, Wilks C, Stuart J, Haussler D and Zhu J. The UCSC Cancer Genomics Browser: update 2013. Nucleic acids research. 2013; 41(Database issue):D949-954. 